\title{
Azido-Neonicotinoids as Candidate Photoaffinity Probes for Insect Nicotinic Acetylcholine Receptors [1]
}

\author{
Peter Maienfischa*, Joerg Haettenschwilera ${ }^{\mathrm{a}}$, Alfred Rindlisbacher ${ }^{\mathrm{b}}$, Arnaud Decock ${ }^{\mathrm{c}}$, \\ Henning Wellmann' ${ }^{\mathrm{C}}$, and Hartmut Kayser ${ }^{\mathrm{C}}$
}

\begin{abstract}
The neonicotinoids are the most successful chemical class of insecticides reaching sales of more than 630 Mio \$ in 2001, mainly due to the excellent market performance of imidacloprid and thiamethoxam. The insect nicotinic acetylcholine receptors (nAChRs) are the targets for these compounds, which are highly effective against a variety of sucking and chewing insects. Compared with the other neonicotinoid sales products, thiamethoxam binds in a different way, possibly to a different site of nAChRs in aphids. To gain further insight into the different modes of binding, a research program applying the photoaffinity labeling technique was started. A series of novel candidate photoaffinity probes containing a 5-azido-6-chloropyridin-3-ylmethyl group were prepared from 5-azido-6-chloropyridin-3-ylmethyl chloride, which was obtained in three steps from 6-chloropyridin-3-ylmethyl chloride. These probes showed good to excellent contact/feeding and systemic activity against Myzus persicae, however, they were at least 4- to 16-fold less effective against Aphis craccivora, Nilaparvata lugens, Spodoptera littoralis, and Diabrotica balteata than the neonicotinoid sales products. In general, the introduction of an azide group at $C(5)$ of the 6-chloropyridin-3-ylmethyl substituent resulted in reduced potency as well as in a narrower pest spectrum. In competition binding assays with $\left[{ }^{3} \mathrm{H}\right]$ imidacloprid, analogues of imidacloprid, clothianidin, thiacloprid and thiamethoxam containing a 5-azido-6-chloropyridin-3-ylmethyl group showed high displacing potency with nAChRs from Aphis and Myzus $\left(K_{\mathrm{i}}\right.$ values: 2 to $\left.27 \mathrm{nM}\right)$ suggesting that these compounds are valuable candidate photoaffinity probes. Taking into account the biological screening activity as well as the receptor binding potency, 1-(5-azido-6-chloropyridin-3-ylmethyl)-2-nitroimino-imidazolidine, N-(5-azido-6-chloropyridin-3-ylmethyl)-N'-methyl-N"-nitroguanidine and 3-(5-azido-6-chloropyridin-3-ylmethyl)-2-cyanoimino-thiazolidine were identified as the preferred candidate neonicotinoid photoaffinity probes to study the imidacloprid binding site.
\end{abstract}

Keywords: Azido-neonicotinoids · Candidate photoaffinity probes · Imidacloprid · Insecticidal activity · Insecticides · Neonicotinoids · Nicotinic acetylcholine receptors · Thiamethoxam

\section{Introduction}

An important milestone in the history of modern insect control is marked by the discovery of the neonicotinoids [2]. These compounds act on nicotinic acetylcholine

\footnotetext{
${ }^{\star}$ Correspondence: Dr. P. Maienfischa

Tel.: + 41613236647

Fax: + 41613238529

E-Mail: peter.maienfisch@syngenta.com

asyngenta Crop Protection AG

Optimisation Chemistry

Schwarzwaldallee 215

$\mathrm{CH}-4002$ Base

bSyngenta Crop Protection AG

Research Biology, Insect Control

Schaffhauserstr. 101

$\mathrm{CH}-4332$ Stein

'Syngenta Crop Protection AG

Biochemistry

Schwarzwaldallee 215

$\mathrm{CH}-4002$ Basel
}

receptors (nAChRs) and are highly effective against a variety of sucking and chewing insects. As the first representative of this chemical class, imidacloprid (1) was introduced to the market in 1991, and since then, a series of analogues (compounds 2 to 7) have been launched (Fig. 1) [3]. Today the neonicotinoids are the fastest growing chemical class of insecticides. This tremendous success is based on their unique chemical and biological properties, such as broad-spectrum insecticidal activity, low application rates, excellent systemic characteristics, favourable safety profile, and a new mode of action.

Our own research in this area resulted in the discovery of thiamethoxam (5) [4]. This compound is a second-generation neonicotinoid and belongs to the thianicotinyl subclass. It was first synthesized in 1991 and is now developed worldwide for use in more than 100 crops. Thiamethoxam is marketed since 1998 under the trademarks Actara ${ }^{\circledR}$ for foliar and soil treatment and Cruiser ${ }^{\circledR}$ for seed treatment. In all these usages, thiamethoxam provides excellent control of a broad range of commercially important pests, such as aphids, whiteflies, thrips, rice hoppers, Colorado potato beetle, flea beetles, wireworms, leaf miners as well as some lepidopterous species [5]. Low use rates, flexible application methods, excellent efficacy, and the favourable safety profile make this new insecticide well suited for modern integrated pest management programs in many cropping systems.

All sales products $\mathbf{1}$ to $\mathbf{7}$ bind with high affinity to nicotinic acetylcholine receptors 
[6][7]. To provide further evidence for our recent findings that thiamethoxam binds, compared to the other neonicotinoid sales products, in a different way, possibly to a different site of the receptor in aphids [7], we have started a research program applying the photoaffinity labeling technique to investigate neonicotinoid-receptor interactions and to identify the amino acids involved in neonicotinoid binding. This article summarises the current status relative to neonicotinoid photoaffinity probes and reports for the first time the synthesis, binding potency and biological activity of the novel candidate photoaffinity probes $\mathbf{1 3}$ to $\mathbf{1 6}$ (Fig. 5).

\section{Photoaffinity Labeling Technique}

Three major approaches are mainly used to study molecular recognition in receptor-ligand interactions [8a]:

1) Spectroscopic methods: X-ray crystallography, high-resolution NMR, etc.

2) Chemical methods: photoaffinity labeling, chemical affinity labeling, etc.

3) Genetic methods: site-directed mutagenesis, molecular chimera, etc.

Among these methods photoaffinity labeling is a very powerful tool for the identification of ligand-binding proteins in crude protein mixtures [8]. This approach uses photolabile derivatives of ligands (photoaffinity probes; see Fig. 2) for the covalent labeling of target proteins, for example enzymes or receptors. Upon absorption of UV-light, photoaffinity probes are converted into highly reactive intermediates, which can covalently bind to amino acid residues at the binding site of target proteins. Subsequently, the radiolabeled protein can be isolated, the labeled amino acids identified and thus the binding domain characterised.

Currently, aryl/heteroaryl azides and aryldiazirines are the photoreactive groups mainly used in photoaffinity labeling generating aryl/heteroaryl nitrenes and aryl carbenes, respectively, as reactive intermediates that can insert directly into most carbon-, nitrogen-, oxygen-, and sulfur-containing covalent bonds (Fig. 2).

\section{Design of Neonicotinoid Photoaffinity Probes}

As the first neonicotinoid photoaffinity probe, the 2-azido-5- ${ }^{125}$ iodobenzoyloxyethyl derivative 8 of an imidacloprid analogue (Fig. 3) has been described [9]. However, this probe is not ideal, because it is of limited hydrolytic stability and only effec-

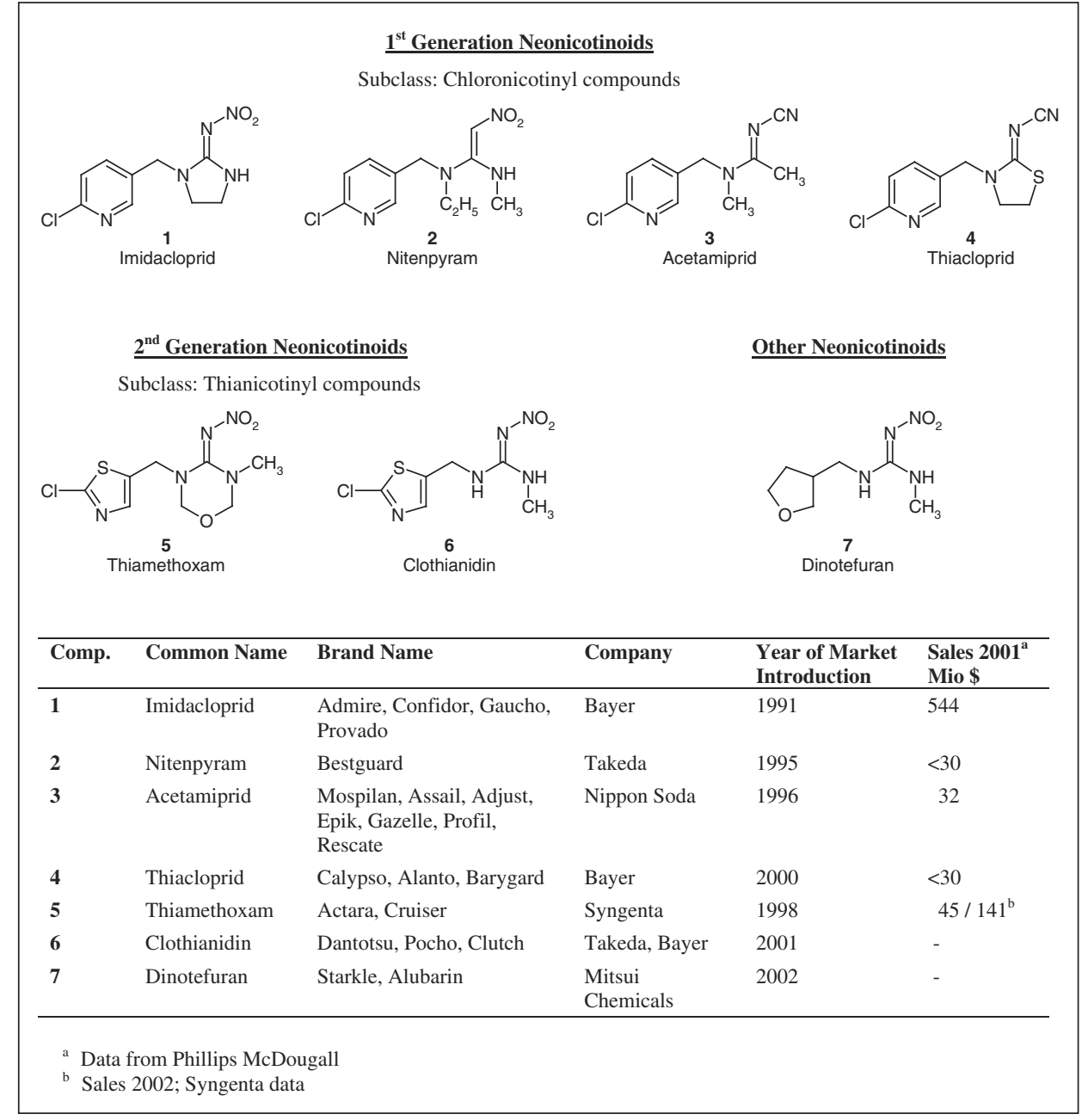

Fig 1. Neonicotinoid sales products

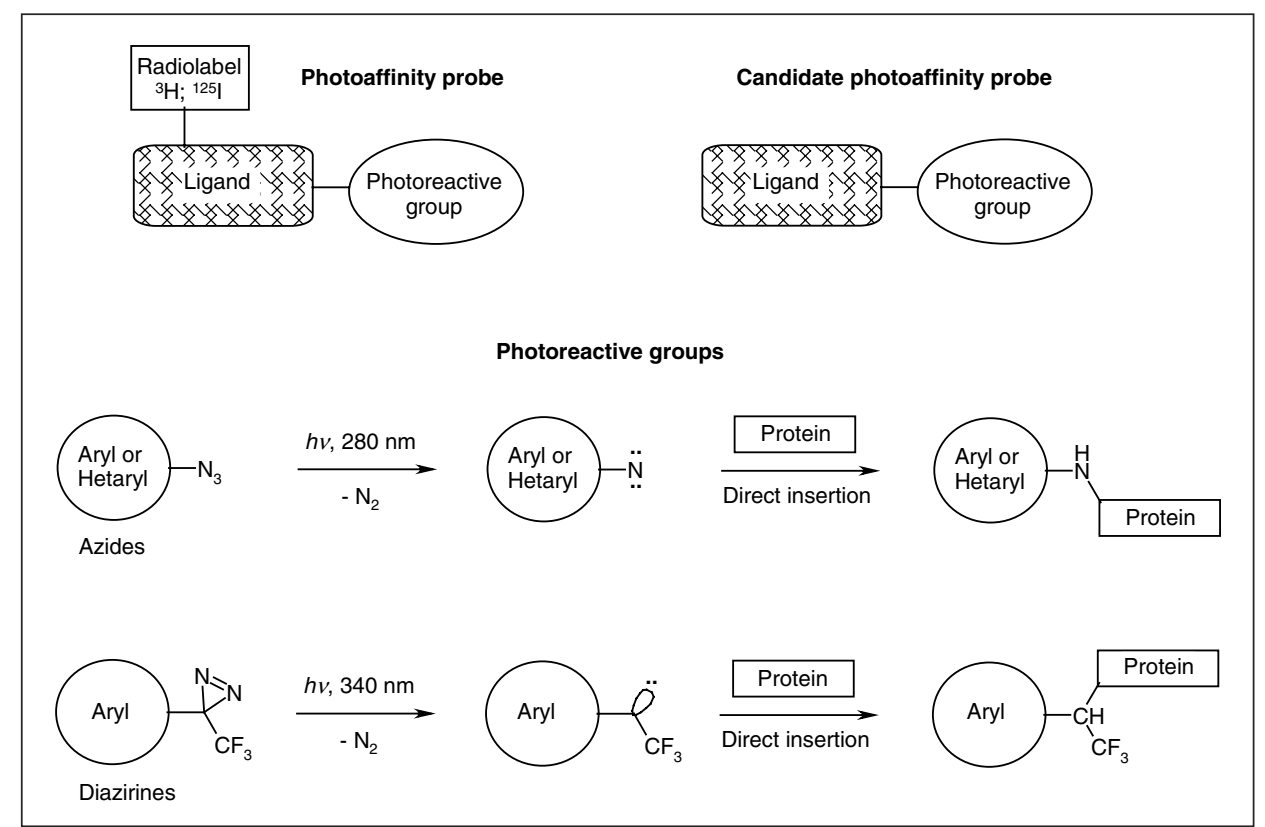

Fig 2. Photoaffinity probes and examples of photoreactive groups used in photoaffinity labeling

tive with receptor proteins from the fly Drosophila, but not with those from other insects. Furthermore, the photoreactive group is in quite some distance from that part of the molecule essential for binding.
This is also the major disadvantage of the two recently published candidate photoaffinity probes $\mathbf{9}$ and $\mathbf{1 0}$, which behaved as typical nicotinic agonists in cockroach nerve cord preparations [10]. 


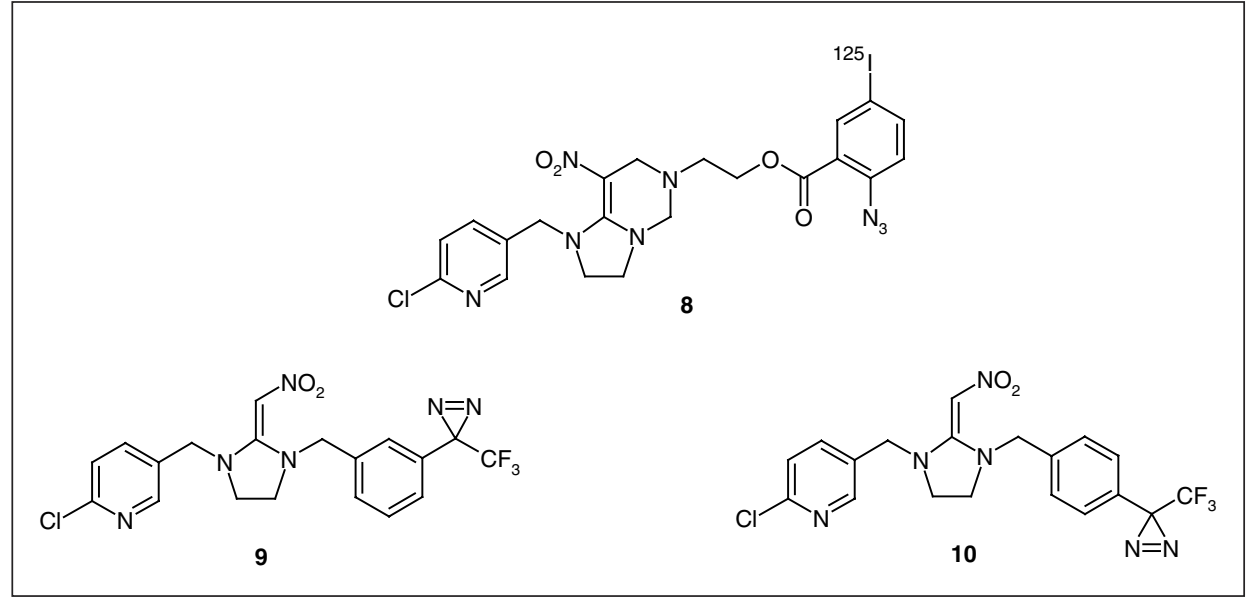

Fig 3. Structures of first neonicotinoid photoaffinity probe $\mathbf{8}$ and of recent candidate probes 9 and 10

SAR for 6-chloropyridin-3-yl methyl substituent
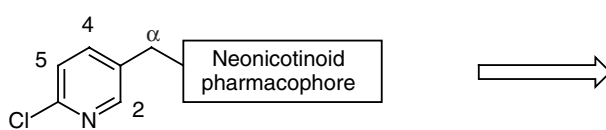

Insecticidal activity against aphids:

2-Position: $\mathrm{H}$ >> other substituents

4-Position: $H$ best substituent

5-Position: $\quad \mathrm{H}=\mathrm{Cl}$

$\alpha$-Position: $\quad \mathrm{H}>\mathrm{Me}>$ other substituents

Fig. 4. Structure-activity relationships of 6-chloropyridin-3-ylmethyl substituted neonicotinoids and design of candidate photoaffinity probes of type $\mathbf{A}$

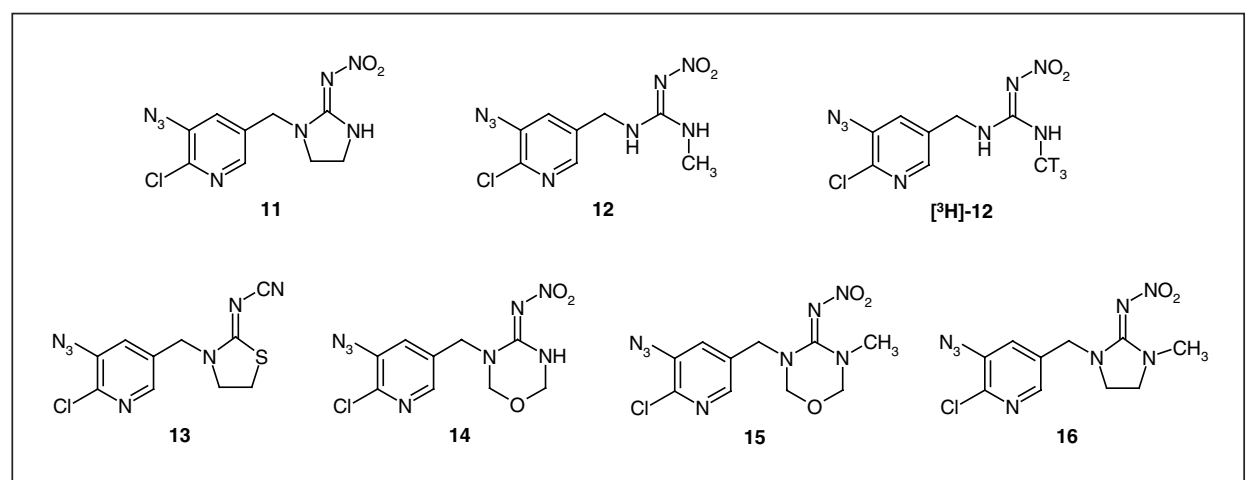

Fig. 5. Structures of candidate photoaffinity probes 11 to 16 and $\left[{ }^{3} \mathrm{H}\right]-12$

The preferred neonicotinoid photoaffinity probe would show nanomolar affinity to nAChRs from insects (e.g. from aphids), possess reasonable insecticidal activity, have the photoreactive group in close proximity to the binding-relevant part of the molecule and be easy to synthesise.

The structure-activity relationships (SAR) developed at Syngenta [11] for the 6-chloropyridin-3-ylmethyl substituent led to the design of candidate neonicotinoid photoaffinity probes of type A (Fig. 4). In collaboration with the group of John E. Casida, compounds 11 and 12 (Fig. 5), both containing a 5-azido-6-chloropyridin-3ylmethyl substituent, were chosen as first overall yield of this four-step synthesis $\mathbf{1 8} \rightarrow \mathbf{1 9} \rightarrow \mathbf{2 0} \rightarrow \mathbf{2 1} \rightarrow \mathbf{1 7}$ was only $7.5 \%$ [12] Therefore, an alternative synthetic route was developed at Syngenta. The key step involved the introduction of the azido group by a metalation reaction employing the strong ortho-directing effect of the 6chloro group. Thus, starting from readily accessible 6-chloropyridin-3-ylmethyl chloride (22), the chloromethyl group was first protected as the morpholin-4-ylmethyl group. The resulting pyridine derivative $\mathbf{2 3}$ was lithiated at $-78^{\circ} \mathrm{C}$ with 2.0 equiv. of lithium diisopropylamide (LDA), and the resulting solution quenched at $-100^{\circ} \mathrm{C}$ with 2.0 equiv. of tosyl azide to afford the azido pyridine $\mathbf{2 4}$ in $45 \%$ yield. Treatment of $\mathbf{2 4}$ with ethyl chloroformate yielded the desired key intermediate 17. By this synthetic approach 17 was obtained in only three steps and in an overall yield of $35 \%$.

The candidate photoaffinity probes $\mathbf{1 1}$ to $\mathbf{1 6}$ were prepared following methodology, which we have already published previously [4b][12-14]. The 5-azido-6-chloropyridin-3-ylmethyl substituent was introduced by alkylation of the nitroimino- or cyanoimino-heterocycles 26, 27, 29, 31, 33 and 34 with the chloride 17 (Scheme 2).

\section{Biological Activity}

The biological activity of the candidate photoaffinity probes $\mathbf{1 1}$ to $\mathbf{1 6}$ was evaluated against five insect species for contact/feeding activity and against Aphis craccivora (A.c.) and Myzus persicae (M.p.) for systemic activity in direct comparison with the neonicotinoid standards imidacloprid (1), thiacloprid (4), thiamethoxam (5), and clothianidin (6). The biological results are shown in Table 1.

Candidate photoaffinity probes $\mathbf{1 1}$ to $\mathbf{1 6}$ showed good to excellent contact/feeding and systemic activity against Myzus persicae. Against all other insects, however, these compounds were at least 4- to 16-fold less effective than the neonicotinoid standards. The broadest spectrum of activity was seen for the azides $\mathbf{1 1}$ and $\mathbf{1 3}$. In general, the introduction of an azide group at $\mathrm{C}(5)$ of the 6-chloropyridin-3-ylmethyl substituent $(\mathbf{1} \rightarrow \mathbf{1 1} ; \mathbf{4} \rightarrow \mathbf{1 3})$ resulted in reduced potency as well as in a narrower pest spectrum.

\section{Synthesis of Candidate Neonicotinoid Photoaffinity Probes}

5-Azido-6-chloropyridin-3-ylmethyl chloride (17) is a key intermediate for the synthesis of the candidate neonicotinoid photoaffinity probes $\mathbf{1 1}$ to $\mathbf{1 6}$. It was first prepared starting from 6-chloro-5-nitronicotinic acid 18 (Scheme 1). However, the

\section{Receptor Binding Potency}

Binding potencies to $\mathrm{nAChRs}$ were measured using membrane preparations from Aphis craccivora and Myzus persicae. Data for the azido compounds $\mathbf{1 1}$ to $\mathbf{1 6}$ and 


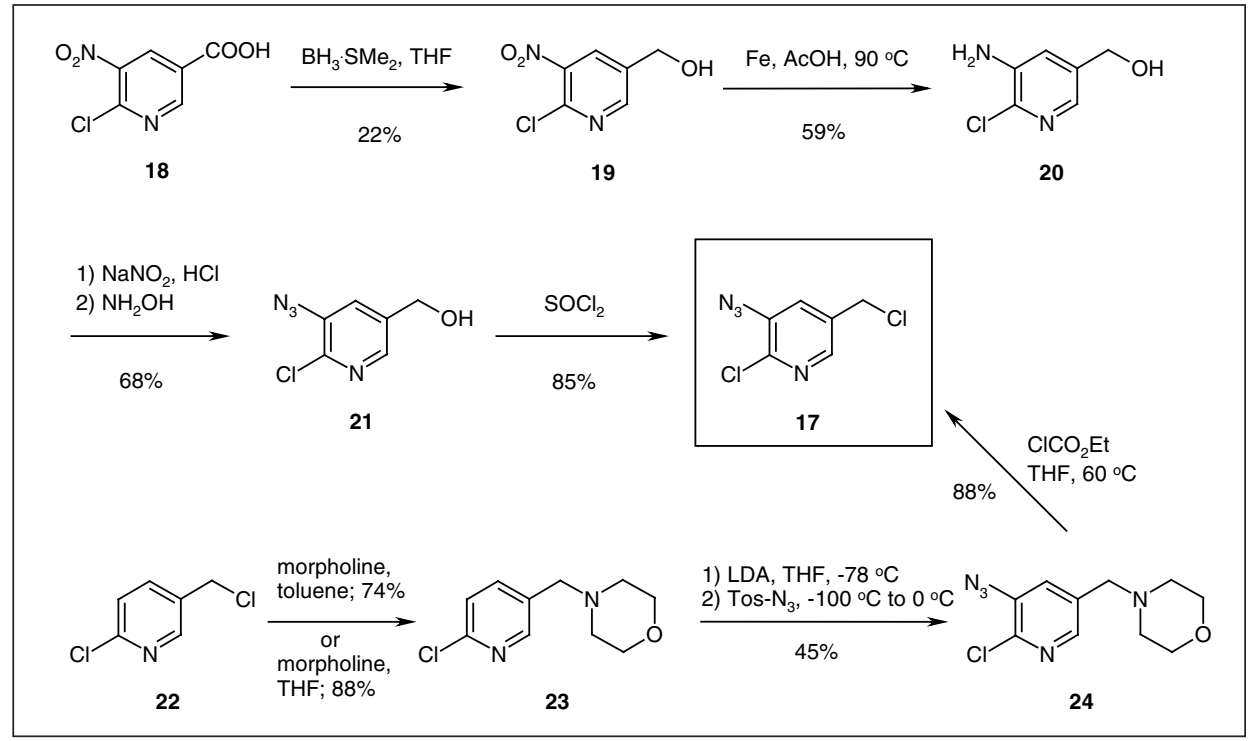

Scheme 1. Synthesis of the key intermediate 5-azido-6-chloropyridin-3-ylmethyl chloride (17)

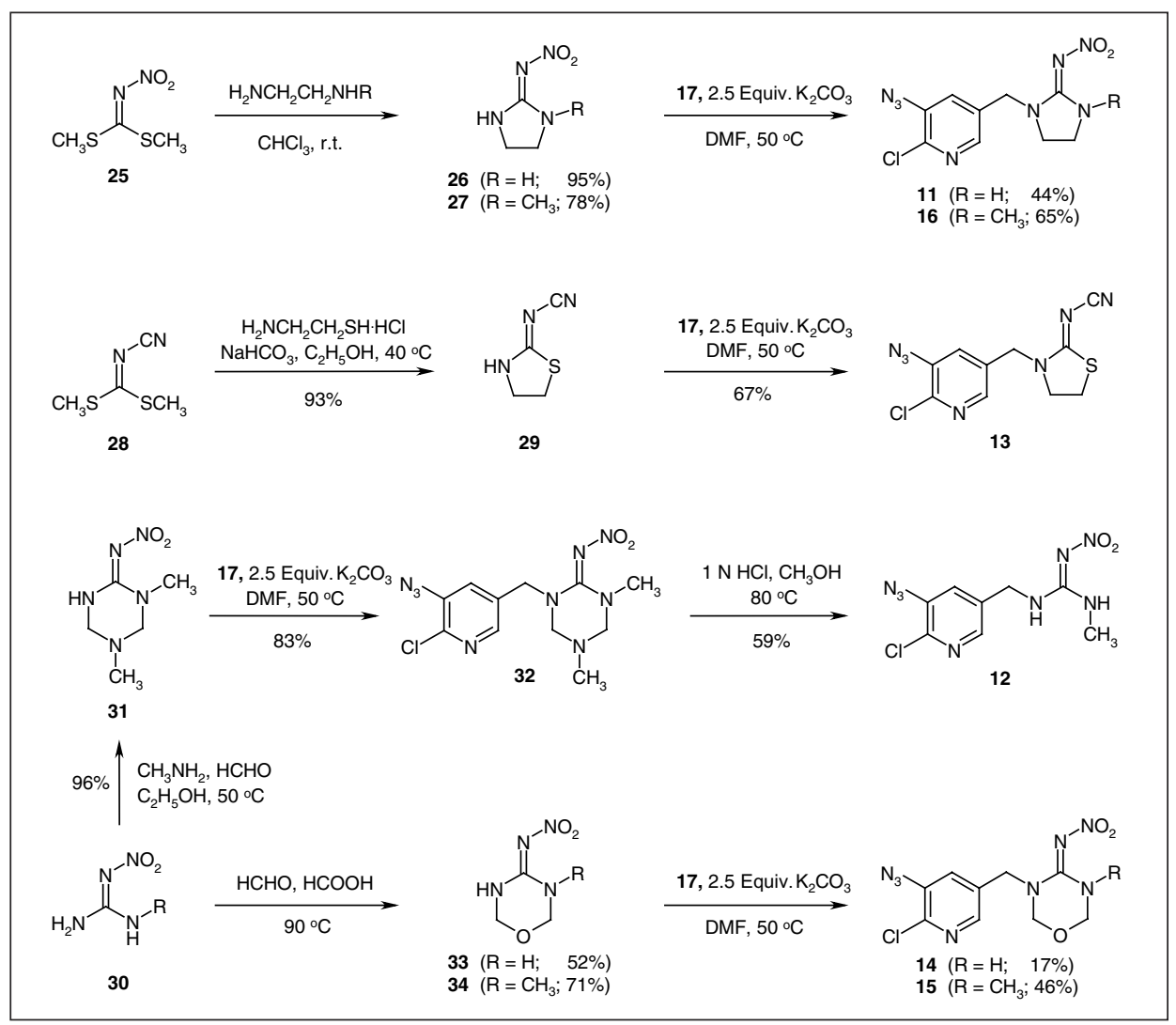

Scheme 2. Synthesis of candidate photoaffinity probes of type A

the neonicotinoid sales products $\mathbf{1}, \mathbf{4}, \mathbf{5}$ and 6 were obtained from competition binding assays with $\left[{ }^{3} \mathrm{H}\right]$ imidacloprid as a ligand that shares its binding characteristics with most other neonicotinoids, with the exception of thiamethoxam [6a][7][17]. Incubations were performed with $100 \mu \mathrm{g}$ of membrane protein and $6 \mathrm{nM}$ of the radioligand for $2 \mathrm{~h}$ at $22^{\circ} \mathrm{C}$.

Our results, together with some data from the literature, are compiled in Table 2 as the inhibition constants $K_{\mathfrak{j}}$, which were calculated from the measured $\mathrm{IC}_{50}$ values
[18]. The imidacloprid analogue 11, the clothianidin analogue 12, the thiacloprid analogue 13 and the thiamethoxam analogue 14 possess high displacing potency with nAChRs from Aphis and Myzus $\left(K_{\mathrm{i}}\right.$ values: 2 to $27 \mathrm{nM}$ ) suggesting that these compounds are valuable candidate photo affinity probes for the imidacloprid binding site. On the other hand, compounds $\mathbf{1 5}$ and $\mathbf{1 6}$ may be more suitable to study the unusual binding of thiamethoxam 5 .

In the meantime, Zhang et al. [15] prepared a series of further azidopyridinyl neonicotinoids as candidate photoaffinity probes. This study demonstrated that 5-azido-6-chloropyridin-3-ylmethyl derivatives are clearly more potent than the corresponding 4-azido analogues. Compounds 35 and 38 and especially the 2-nitroimino-thiazoline $\mathbf{3 6}$ and the 2-nitroimino-imidazolidine 37 were found to be very potent in displacing $\left[{ }^{3} \mathrm{H}\right]$ imidacloprid from Drosophila nAChRs (Table 2, Fig. 6).

\section{Conclusion}

Candidate photoaffinity probes $\mathbf{1 1}$ to $\mathbf{1 6}$, all containing a 5-azido-6-chloropyridin 3 -ylmethyl group, were successfully prepared from 5-azido-6-chloropyridin3 -ylmethyl chloride, which was obtained in three steps from 6-chloropyridin3 -ylmethyl chloride. Taking into account the biological screening activity (Table 1) as well as the receptor binding potency (Table 2) we conclude that compounds 11, $\mathbf{1 2}$, and $\mathbf{1 3}$ are the preferred candidate neonicotinoid photoaffinity probes to investigate neonicotinoid-receptor interactions and to identify the amino acids involved in imidacloprid binding. Although only limited data are available compounds $\mathbf{3 6}$ and $\mathbf{3 7}$ may also be considered as valuable candidates.

Among these azido-neonicotinoids, a radiolabel is most easily introduced into the acyclic nitroguanidine derivative $\mathbf{1 2}$ and consequently $\left[{ }^{3} \mathrm{H}\right]-\mathbf{1 2}$ (Fig. 5) was radiosynthesized with high specific activity as first azido-neonicotinoid photoaffinity probe. $\left[{ }^{3} \mathrm{H}\right]-12$ was found to bind to a single high-affinity site in Myzus that is competitively inhibited by imidacloprid [16]

Received: September 26, 2003

[1] Presented in part at the 10th IUPAC International Congress of the Chemistry of Crop Protection, Basel, Switzerland, 2002, Poster 3a.16 (book of abstracts Vol.1, p 234).

[2] I. Yamamoto, J.E. Casida (Eds), 'Nicotinoid Insecticides and the Nicotinic Acetylcholine Receptor', Springer-Verlag, Tokyo, 1999, 1-300; and literature cited therein.

[3] a) P. Maienfisch, F. Brandl, W. Kobel, A. Rindlisbacher, R. Senn in: 'Nicotinoid Insecticides and the Nicotinic Acetylcholine Receptor', Eds. I. Yamamoto, J.E. Casida, Springer-Verlag, Tokyo, 1999, 177-209; and literature cited therein. b) T. Wakita, K. Kinoshita, E. Yamada, N. Yasui, N. Kawahara, A. Naoi, M. Nakaya, K. Ebihara, H. Matsuno, H. Kodaka, Pest Manag. Sci. 2003, 50, 1016-1022. 
Table 1. Biological activity of candidate photoaffinity probes $\mathbf{1 1}$ to $\mathbf{1 6}$ in comparison with the neonicotinoid standards $1,4,5$, and 6

\begin{tabular}{|c|c|c|c|c|c|c|c|}
\hline Comp. & $\begin{array}{l}\text { A.c. } \\
\text { cf }^{\mathrm{f}}\end{array}$ & $\begin{array}{l}\text { A.c. } \\
\text { sy }^{\mathrm{g}}\end{array}$ & $\begin{array}{l}\text { M.p. } \\
\text { cf }\end{array}$ & $\begin{array}{c}\text { M.p. } \\
\text { sy }\end{array}$ & $\begin{array}{l}\text { N.l. } \\
\text { cf }\end{array}$ & $\begin{array}{l}\text { S.l. }^{\mathrm{d}} \\
\mathrm{cf}\end{array}$ & $\begin{array}{l}\text { D.b. } \\
\text { cf }\end{array}$ \\
\hline 11 & ++ & ++++ & +++ & +++++ & - & ++ & +++ \\
\hline 12 & ++ & +++ & +++ & +++++ & + & - & - \\
\hline 13 & + & +++ & ++ & +++ & - & + & +++ \\
\hline 14 & - & - & +++ & +++++ & - & - & - \\
\hline 15 & + & +++ & ++ & +++++ & + & - & - \\
\hline 16 & - & - & + & +++++ & - & + & - \\
\hline 1 & +++ & +++++ & +++++ & +++++ & ++++ & ++++ & +++++ \\
\hline 4 & +++ & ++++ & +++ & +++++ & + & ++ & +++++ \\
\hline 5 & +++ & +++++ & +++++ & +++++ & +++++ & ++++ & +++++ \\
\hline 6 & ++ & +++++ & ++++ & +++++ & +++++ & ++++ & +++++ \\
\hline Test insects: & \multicolumn{7}{|c|}{$\begin{array}{l}{ }^{\mathrm{a}} \text { Aphis craccivora, }{ }^{\mathrm{b}} \text { Myzus persicae },{ }^{\mathrm{c}} \text { Nilaparvata lugens, }{ }^{\mathrm{d}} \text { Spodoptera littoralis, } \\
{ }^{\mathrm{e}} \text { Diabrotica balteata. }\end{array}$} \\
\hline \multicolumn{8}{|c|}{ Type of activity: ${ }^{\mathrm{f}}$ Contact/feeding activity, ${ }^{\mathrm{g}}$ systemic activity. } \\
\hline Rating system: & \multicolumn{7}{|c|}{$\begin{array}{l}\text { - denotes }<80 \% \text { activity at } 200 \mathrm{ppm} ;+ \text { denotes } \geq 80 \% \text { activity at } 200 \mathrm{ppm} ; \\
++ \text { denotes } \geq 80 \% \text { activity at } 50 \mathrm{ppm} ;+++ \text { denotes } \geq 80 \% \text { activity at } 12 \mathrm{ppm} ; \\
++++ \text { denotes } \geq 80 \% \text { activity at } 3 \mathrm{ppm} ;+++++ \text { denotes } \geq 80 \% \text { activity at } 0.8 \mathrm{ppm} \\
\text { or below. See [4b] for details of the assays. }\end{array}$} \\
\hline
\end{tabular}

Table 2. Competition binding potency of candidate photoaffinity probes of type $\mathbf{A}$ with $\left[{ }^{3} \mathrm{H}\right] \mathrm{imi}-$ dacloprid $\left(\left[{ }^{3} \mathrm{H}\right]-1\right)$

\begin{tabular}{ccc} 
Comp. & & \\
& A.c. $^{\text {a }}$ & \\
\hline 11 & $4.5^{\text {d }}$ & - \\
& - \\
12 & 22 \\
& - \\
13 & 2 \\
14 & 8 \\
15 & 125 \\
$\mathbf{1 6}$ & 123 \\
$\mathbf{1}$ & 6 \\
4 & 3 \\
$\mathbf{5}^{\mathrm{f}}$ & 2300 \\
$\mathbf{6}$ & 14 \\
$\mathbf{3 5}$ & - \\
$\mathbf{3 6}$ & - \\
$\mathbf{3 7}$ & - \\
$\mathbf{3 8}$ & -
\end{tabular}

\begin{tabular}{|c|c|c|}
\hline \multicolumn{2}{|c|}{$K_{\mathbf{i}}[\mathbf{n M}]$} & \multirow[t]{2}{*}{ Reference } \\
\hline M.p. ${ }^{b}$ & D.m. ${ }^{c}$ & \\
\hline $\begin{array}{c}4.5^{\mathrm{d}} \\
1.0 \\
-\end{array}$ & $\begin{array}{l}-\mathrm{e} \\
15 \\
24\end{array}$ & $\begin{array}{l}\text { This study } \\
\text { Kagabu et al. }[12] \\
\text { Zhang et al. }[15]\end{array}$ \\
\hline $\begin{array}{l}27 \\
4.5 \\
5.0\end{array}$ & $\begin{array}{c}- \\
13 \\
161\end{array}$ & $\begin{array}{l}\text { This study } \\
\text { Kagabu et al. }[12] \\
\text { Tomizawa } \text { et al. }[16\end{array}$ \\
\hline 2.5 & - & This study \\
\hline 11 & - & This study \\
\hline 160 & - & This study \\
\hline 270 & - & This study \\
\hline 3 & - & This study \\
\hline 2 & - & This study \\
\hline 3200 & - & Kayser et al. [17] \\
\hline 9 & - & This study \\
\hline- & 13 & Zhang et al. [15] \\
\hline- & 3.9 & Zhang et al. [15] \\
\hline- & 0.72 & Zhang et al. [15] \\
\hline- & 28 & Zhang et al. [15] \\
\hline
\end{tabular}

${ }^{\mathrm{a}}$ Aphis craccivora,${ }^{\mathrm{b}}$ Myzus persicae, ${ }^{\mathrm{c}}$ Drosophila melanogaster

${ }^{\mathrm{d}}$ See [6a] for assay description, ${ }^{\mathrm{e}}$ not tested

${ }^{\mathrm{f}}$ Thiamethoxam (5) binds in a mode different from that of the other neonicotinoid sales products, i.e. it interferes in a non-competitive mode with $\left[{ }^{3} \mathrm{H}\right]$ imidacloprid (1) binding to receptor preparations from A.c. and M.p., which explains the high $K_{\mathrm{i}}$ values. The intrinsic receptor affinity of thiamethoxam, used as $\left[{ }^{3} \mathrm{H}\right]-\mathbf{5}$, is in the nanomolar range, comparable to that of imidacloprid (1).
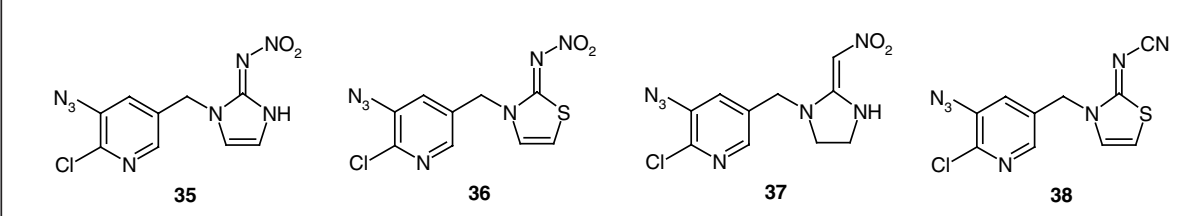

Fig. 6. Structures of candidate photoaffinity probes of type A recently published [15]
[4] a) P. Maienfisch, L. Gsell, A. Rindlisbacher, Pestic. Sci. 1999, 55, 351-355; b) P. Maienfisch, H. Huerlimann, A. Rindlisbacher, L. Gsell, H. Dettwiler, J. Haettenschwiler, E. Sieger, M. Walti, Pest Manag. Sci. 2001, 57, 165-176; c) P. Maienfisch, A. Rindlisbacher, H. Huerlimann, J. Haettenschwiler, A.K. Desai, V.S. Ekkundi, V.D. Gangan, ACS Symposium Series, 2002, 800 (Synthesis and Chemistry of Agrochemicals VI), 219-230.

[5] a) R. Senn, D. Hofer, T. Hoppe, M. Angst, P. Wyss, F. Brandl, P. Maienfisch, L. Zang, S. White, Brighton Crop Protection Conference-Pests and Diseases, 1998, Vol. 1 , 27-36; b) P. Maienfisch, M. Angst, F. Brandl, W. Fischer, D. Hofer, H. Kayser, W Kobel, A. Rindlisbacher, R. Senn, A. Steinemann, H. Widmer, Pest Manag. Sci. 2001, 57, 906-913.

[6] a) P. Wiesner, H. Kayser, J. Biochem. Mol. Toxicol. 2000, 14, 221-230; b) A. Zhang, H. Kayser, P. Maienfisch, J.E. Casida, J. Neurochem. 2000, 75, 1294-1303; and literature cited therein.

[7] H. Kayser, C. Lee, H. Wellmann, 10th IUPAC International Congress of the Chemistry of Crop Protection, Basel, Switzerland, 2002, Poster 3c.23 (book of abstracts Vol.1, p 305).

[8] For recent reviews on photoaffinity labelling see: a) Y. Hatanaka, Y. Kanaoka, Heterocycles, 1998, 47, 625-632; b) F. Kotzyba-Hilbert, I. Kapfer, M. Goeldner, Angew. Chem. Int. Ed. Engl. 1995, 34, 1296-1312; c) H.J. Schafer, A. Schuhen, Biol. Res. 1996, 29, 31-46; d) J.E. Casida, G.B. Quistad, Special Publication - Royal Society of Chemistry, 1999, 232 (Progress in Neuropharmacology and Neurotoxicology of Pesticides and Drugs), 34-45; e) C.A. Gartner, Curr. Med. Chem. 2003, 10, 671-689.

[9] a) B. Latli, M. Tomizawa, J.E. Casida, Bioconjug. Chem. 1997, 8, 7-14; b) M. Tomizawa, J.E. Casida, Neurosci. Lett. 1997, 237, 61-4.

[10] K. Matsuda, M. Ihara, K. Nishimura, D.B. Sattelle, K. Komai, Biosci. Biotechn. Biochem. 2001, 65, 1534-1541.

[11] The work started at Ciba-Geigy, which became Novartis in 1996, and then Syngenta in 2000.

[12] S. Kagabu, P. Maienfisch, A. Zhang, J. Granda-Minones, J. Haettenschwiler, H Kayser, T. Maetzke, J.E. Casida, J. Med. Chem. 2000, 43, 5003-5009.

[13] P. Maienfisch, H. Huerlimann, J. Haettenschwiler, Tetrahedron Lett. 2000, 41, 7187-7191

[14] A. Zhang, H. Kayser, P. Maienfisch, J.E. Casida, J. Neurochem. 2000, 75, 1294-1303

[15] N. Zhang, M. Tomizawa, J.E. Casida, $J$. Med. Chem. 2002, 45, 2832-2840.

[16] M. Tomizawa, Z. Wen, H.L. Chin, H. Morimoto, H. Kayser, J.E. Casida, J. Neurochem. 2001, 78, 1359-1366.

[17] H. Kayser, C. Lee, A. Decock, M. Baur, J. Haettenschwiler, P. Maienfisch (manuscript in preparation).

[18] Y.-C. Cheng, W.H. Prusoff, Biochem. Pharmacol. 1973, 22, 3099-3108. 